\title{
Grundtvigs ældste Udkast til Digtet om Kong Skjold
}

Af Gustav Albeck.

I sin interessante og stofmættede Afhandling om Grundtvig og den danske Rimkrønike (Grundtvig-Studier I954, p. 40-96) har Dr. Helge Toldberg redegjort for de forskellige Stadier i Grundtvigs Omog Gendigtninger af Rimkrønikens Afsnit om Kong Skjold (se især nævnte Afhandling p. 76, 78 og 8I-86). Interessen samler sig naturligt om Grundtvigs selvstændige Bidrag til Udformningen af Skjoldsmyten, der med Rette karakteriseres som imponerende: »Bedriften består $\mathrm{i}$ at Grundtvig har skabt en situation der $\mathrm{i}$ poetisk værd stod mål med Beowulfs skildring af Skjolds bortfærd, men samtidig i kraft af emnet havde en frejdigere tone og mere æventyrmæssig fremstilling « (anf. Afhandl. p. 83).

Saa langt kan man være enig med Dr. Toldberg. Derimod er det vanskeligt at følge ham, naar han i Fortsættelse heraf hævder, at Grundtvigs »etymologiske raptus, det mest vidtdrevne udslag af hans associationstrang ... (kom) ham til hjælp ved at forære ham neget.« Toldberg fortsætter sin Udredning med følgende Fremstilling: »Om Skjolds herkomst oplyser det angelsaksiske kvad ikke andet end at han er Scyld Scefing, Scefs søn Skjold. I navnet Scef griber Grundtvig nu ordet for neg, nyengelsk sheaf. Kombineret med sagnet om at Skjold er kommet til landet med et skib, uden at nogen vidste hvorfra eller hvordan, bliver det til at det lille barn er kommet sejlende med et neg under hovedet. Det er et rent poetisk fund, for Grundtvig fastholder ellers den videnskabelige forklaring paa ordet Scefing.«

Det synes, som Dr. Toldberg her har tillagt Grundtvigs poetiske Syn og myteskabende Evner en større Indsats, end det foreliggende Kildemateriale tillader det. Billedet af det lille Kongebarn med Neget under sit Hoved er ikke Grundtvigs Opfindelse, en Frugt af hans po- 
etiske Syn. Billedet stammer, som Grundtvig oplyser i sin Indledning og Fortale til Bjowulfs Drape af Angel-Saxisk fordansket etc. (1820), p. XXXVIII fra »to af det tolvte Aarhundredes Forfattere Vilhelm af Malmesbury og Simeon af Dunhelm ...«, der har det Tillæg til Sagnet om Kong Sceaf, »at Barnet kom tillands, slumrende paa en Korn-Neeg og fik deraf Navnet Scef eller Sceaf.«

Allerede i i 8 i 7 har Grundtvig - vel at mærke i en videnskabelig Afhandling (Om Bjovulfs Drape eller det af Hr. Etatsraad Thorkelin 1815 udgivne angelsachsiske Digt) - overført Neget fra ScefSagnet til Skjold. I en Fodnote til nævnte Afhandling (Danne-Virke, I8I7 p. 217-218) skriver Grundtvig i Tilknytning til en smuk Redegørelse for Beowulfs Skjold-Afsnit bl. a. følgende:

»Dette er da den utvivlsomme Indhold, det veemodig rørende Sagn om Dannemarks Skjold, hvoraf man seer, at de Gamle har fortalt om ham, hvad Ethelverd og Vilhelm af Malmesbury og Simeon Dunelmensis, paa Lidet nær eenstemmig, fortælle om hans Fader Scef, Sceaf, Seaf, at han, som et Barn sovende paa en Neeg (sceaf) hvoraf han fik Navn, og eenlig paa en Snekke fuld af Vaaben, kom drivende til Skandinavien. Sædvanlig hedder det at han blev Konge i Slesvig (hos Anglerne) men Ethelverd siger han blev det i Scani. Ogsaa i Landfedgatal finde vi dette Sagn, og det synes klart, at det i Oldtiden maa have giældt Skjold, siden man veed meget om ham, men intet videre om Scef at fortælle, ligesom det var rimeligst, at den Fundne som laae mellem Vaaben og blev Landets Skjold, fik dette Navn med Tillægget Scefing (Negens Søn) som et Ax af forborgen Rod. Hermed stemmer ogsaa overeens, at Saxe-Krøniken har en Scef der fødtes i Arken, som Landfedgatal kalder Bedvig Sceefing, ligeledes det, at man selv i Norden tillægger Skjold en vidunderlig Herkomst, da Islænderne giøre ham til en Søn af Odin, og Saxo til Søn af Lother, som vel turde have Sammenhæng med Lodur i Volu-Spa. Saameget er vist, og i Grunden det Vigtigste, at det er gammel-dansk at ansee KongeStammen, som Konge-Banneret for en Himlens Gave, og gid kun aldrig det Syn maa vorde regnet mellem de tabte Oldsager, saa lader alt andet Tab sig erstatte!«

Det fremgaar af ovenstaaende Citat, at Grundtvig i 1817 med saglige Argumenter søger at sandsynliggøre den These, at Sagnet om Kongebarnet, der kom paa et Skib med Vaaben og Rustninger, men som hvilede sit Hovede paa et Neg, »i Oldtiden maa have giældt Skjold «. At dette Synspunkt videnskabeligt har dannet Skole, fremgaar bl. a. af Axel Olriks Danmarks Heltedigtning (1903), hvor Grundtvig omtales som Talsmand for den videnskabelige Anskuelse, at Skjold (i Modsæetning til Skeaf) er den rette Stamfader, og at 
hans Tilnavn Sceafing blot betyder »Negets Søn« eller »han med Kornneget« (I, p. 236).

En anden Ting er, at Grundtvigs sagnhistoriske These ogsaa stemte vel med hans poetiske Holdning og Psyche. Slutningen af Citatet fra Dannevirke-Afhandlingen røber, at han har en ny nationalhistorisk Mythe i Tankerne, en Parallel til Sagnet om det himmelsendte Banner fra Estlandsslaget. Og hvorom alting er, kan der ikke herske Uenighed om, at det senere lykkedes for Grundtvig at udforme denne Mythe med stor poetisk Kraft.

Dr. Toldberg fremhæver, at Grundtvig har Besvær med at faa Afsnittet om Skjolds Komme klemt ind i Rimkrønikens »Jeg《-Form : 》I Dodanim-redaktionen fremstilles det hele i 2. person af de gubber, han har spurgt om sit ophav; i i 826-redaktionen (jf. PS V, s. 396) er det en af to mulige forklaringer, og i i 834-teksterne (jf. PS VI s. 78) er det en hvidhåret skjald der kvæder visen om det for ham.« (Anf. Afhandl. p. 83).

Det er bl. a. Toldbergs Fortjeneste at have fremdraget det, han kalder Dodanim-Redaktionen (der foruden Rimene om Skjold indeholder Rimene om Humble, Dan, Humble Dans-Søn, Lotther og Gram (anf. Afhandl. p. 73-78). De findes paa 4 Blade i GrundtvigArkivet, fasc. 288. Toldberg har store Vanskeligheder ved at naa til en sikker Datering af disse Blade. Afmærkningen (tre Prikker i Stedet for I. J. N.) peger paa Tiden efter 1823-I824, mens Skrifttrækkene minder »mere om oversættelsesårenes end I826-redaktionens《. Toldberg konkluderer lidt mismodigt: »Hvis man vidste, hvornår Grundtvig fik sine første briller, kunne det måske hjælpe til løsningen.« (Anf. Afhandl. p. 73).

Det synes helt sikkert, at Dodanim-Redaktionen for en Del ligger til Grund for den Gen- og Omdigtning af Den gamle danske Rimkrønike, som Svend Grundtvig fandt blandt Faderens efterladte $\mathrm{Pa}$ pirer, og som han har trykt i PS V, p. 39I-398. (Toldberg, anf. Afhandl. p. 72). Svend Grundtvig har dateret denne Version til 1826, dog saaledes, at Fortsættelsen (PS V, p. 398-4o6) »Rimene 7-17 ... nok, baade efter indre Mærker og efter Skrift og Papir at dømme« er »fra et af de følgende Aar« (PS V, p. 390, Fodnote I ). Endvidere har han paa Ms. til 7-17 skrevet »1826 (28?)《 (Toldberg, anf. Afhandl. p. 72). Rimet om Skjold er Nr. 5 og er saaledes, om Svend Grundtvigs Datering er rigtig, fra I826. Toldberg mener, at denne Datering er korrekt: »de er skrevet på papir med Klippan- 
vandmærket med årstallet $\mathrm{I} 824$, og dette synes Grundtvig at være holdt op med at bruge $1826 . \ll$

Dodanim-Redaktionen maa derfor, dersom man godtager baade Svend Grundtvigs og Helge Toldbergs Dateringskriterier, være blevet til et Sted mellem 1823 og 1826 .

Et Spørgsmaal er det imidlertid, om ikke Dodanim-Redaktionens Tilblivelse af andre Grunde maa fastsættes til r828. Et Fund af et Fragment af en Version af Skjolddigtet synes at berettige dette Spørgsmaal.

Det paagældende Fragment findes i Fasc. 403 c, der - som Svend Grundtvig har angivet det paa et Stykke blaat Papir, han har benyttet til Omslag om Fascikelafsnittet - rummer »Mss. Udkast til Iste Udg. (af Krønike-Riim). Fundne efter 3 dje udgave i875. (Heri mange tillæg, som skulde været medtagne).«

Dette nyfundne Ms. til en Version af Skjolddigtet (Fasc. $403 \mathrm{c}$, fol. I4 r) ęr et Fragment, idet Digtets Begyndelse mangler. Bladet er iøvrigt kun beskrevet paa r-Siden. Dets Forekomst blandt Udkast til Krønike-Riim I ( 1829 ), kunde tyde paa, at dets Tilblivelsestid falder sammen med disses -. Papirsorten med det saakaldte SMSVandmærke er hyppigt benyttet til de andre Manuskripter i Fasciklen. Skriften afviger ikke mærkbart fra Skriften paa de andre Mss.

Svend Grundtvig har opfattet Ms. som en Del af et Udkast til et Krønikerim, idet han med Blyant har forsynet Fragmentet med en hypotetisk Titel: [Danskerne]. Han maa med andre Ord have opfattet det som et Paralleldigt til saadanne Digte i Krønike-Riim, I, som Araberne (p. 52-54), Frankerne (p. 54-56), Normannerne (p. 68-7 I) og Nederlcenderne (p. 90-95), der i Modsætning til Krønnike-Rimenes mange »Jeg《-Digte er »Vi«-Digte, hvori de paagældende Folk taler om deres Indsats og Mission i Historien.

Fragmentet har følgende Indhold :

I Men hvem der lagde dig deri, Det veed kun Gud og ikke vi!

Raadvilde vi paa Tinge sted

Og savned Kvist af Konge-Rod,

5 Da kom et Skib til Isse-Fjord

- For fulde Seil med dig ombord!

- Der laae du spæd i Purpur-Svøb

- Paa Mos og grønne Bøge-Løv,

- Til Hoved-Pude havde du 
Io En Tvilling-Neg af Byg og Rug,

- Men ladet var din [] Vugge sær

- Med Sølv og Guld og Skjold og Sværd,

- Med Klædebon til Kamp og Pragt,

- Med Sørge-Tøj, og Hæders-Dragt!

I5 Da reiste sig igien vort Mod,

- Vi satte Negen paa sin Rod,

- Og satte dig med Gammen op

- Til Konge-Sæde i dens Top,

. Vi skimted Bod for Konge-Savn,

20 Og gav dig Skjold til Konge-Navn!

Til Sammenligning anføres de 34 første Linier af Skjold-Afsnittet af Dodanim-Redaktionen (jf. Toldberg, anf. Afhandling, p. 76-77) :

I15 Mig kaldte Mange Odins Søn

Og jeg mig kalder Hans i Løn;

Thi da som Dreng ved Danmarks Styr

Jeg spurgte om min Ætt og Byrd,

Da sagde mig de Gubber graae:

I 20 Din Vugge gik paa Bølgen blaa, //

(v3) Men hvem der lagde dig deri,

Det veed kun Gud, og ikke vi!

Der kom et Skib til Isse-Fjord

For fulde Seil, med dig ombord,

I25 Og ellers ingen Moders Sjæl, Saa Skibet skiøddede sig selv!

Der laae du spæd i Purpur-Svøb

Paa Mos og grønne Bøge-Løv,

Til Hoved-Pude havde du

i30 En Tvilling-Neg af Byg og Rug,

Og Vuggen var for Resten fuld,

Af Staal og Jern, og Sølv og Guld*)

Af Rustninger og Klædebon,

Som røbed Alt en konstig Haand!

135 Det var just i den dyre Tid,

Da rundt om Land var Tvist og Splid,

Da uden Lov, og uden Drot,

Hver gjorde hvad han fandt for godt,

De Store sloges om de Smaa,

I4o Og Smaa-Folk om en Gaase-Taa!

Thi var du, under Kongeflag,

Os som en buden Hellig-Dag,

For Vaande stor vi skimted Bod,

Vi satte Negen paa sin Rod,

*) Ovenover overstreget: Af Rustninger, af Sølv og Guld. 
I45 Og satte dig med Gammen op

Til Konge-Sæde i dens Top,

Og raabde: længe leve $S k j o l d$,

Os til en Lande-Værger bold!

Den verbale Sammenhæng mellem de to Texter er iøjnespringende. Forholdet tager sig opstillet skematisk saaledes ud:

Fuld (eller næsten fuldstændig) Identitet:

\begin{tabular}{|c|c|c|}
\hline »Krønikerimet« & & danimredakt \\
\hline V. $\quad \mathrm{I}-2$ & $=$ & V. $12 \mathrm{I}-122$ \\
\hline$-\quad 5^{-6}$ & $=$ & $-\mathrm{I} 23-\mathrm{I} 2$ \\
\hline$-7-10$ & $=$ & $-\quad 127-13$ \\
\hline I6-I8 & $=$ & $144^{-1} 4^{(}$ \\
\hline
\end{tabular}

Varierende Udtryk for samme Motiv eller Situation:

»Krønikerimet « :

V. $3-4$

- II-I4

- $\quad 19$

- 20
»Dodanimredaktionen«:

V. $135^{-1} 4^{2}$

- I3I-I34

- 143

- 147

»Krønikerimet《 har den korteste (og poetisk set mest vellykkede) Text. Den savner ganske de »folkelige « Udtryksformer: »ingen Moders Sjæl «, »en buden Hellig-Dag« »og Smaafolk om en Gaase-Taa « o. lgn., der præger alle Dodanimtexterne (jf. Toldberg, anf. Afhandl, p. 79), og, hvad der er mere sigende, den nævner - ligesom Beowulf - intet om, at Kongesavnet forstærkes gennem Splid i Landet, et Motiv, der præger alle Grundtvigs senere Udformninger af Skjoldmotivet. Alene af den Grund maa det anses for saare sandsynligt, at den er ældre end Dodanim-Texten.

Er dette Tilfældet, fører vor lille Undersøgelse til det Resultat, at Grundtvigs forste (selvstændige) poetiske Udformning af Myten om Skjolds Komme til Danmark er blevet til som et Led i hans Arbejde med Krønikerimene, et Arbejde, som efter de bevarede Mss. i Fasc. 403 at dømme maa tidsfæstes til Efteraaret 1828 .

Det er ovenf. omtalt, at Grundtvig i sin Omdigtning af Rimkrøniken har stort Besvær med at faa Skildringen af Skjolds Komme bragt ind i Krønikens »Jeg«-Form. Vanskelighederne bliver poetisk 
og menneskeligt forklarlige derved, at Skildringen oprindelig er udformet som et Krønike-Riim i »Vi«-Form.

Krønikerimet blev ikke færdigt. Det er nævnt, at kun r-Siden af Ms. er beskrevet, og det kan tilføjes, at den ikke er fuldt beskrevet. Grundtvig har muligvis ikke kunnet komme videre i det planlagte Digt om Danskerne. Hensigten har vistnok været at forme Digtet som en Hyldest til det fredsæle og poetiske Danmark, der har været begunstiget af milde og gode Konger, Efterkommerne af den gudsendte Skjold. Tanken kommer til Udtryk i det Digt Danmark, som er det næstsidste blandt Krønike-Riimene fra I829 (p. I28-I3I), og som er et »Jeg«-Digt, formet i Versemaalet fra Grundtvigs elskede Danne-Virke-Vise. Heri siger »Jeg'et«, Danmark, udtrykkelig om Skjold :

$$
\begin{aligned}
& \text { Immer dog han er min egen, } \\
& \text { Drotten slumrende paa Negen, } \\
& \text { Vugget mild paa Orlogs-Snekke, } \\
& \text { Inden Skjolde-Vægge! }
\end{aligned}
$$

Dette er Grundtvigs første trykte Udformning af Skjoldsmyten. I en Note om Skjold (Krønike-Riim, I, I829, p. I6I) omtaler han Beowulf-Beretningen om Skjold og nævner, at Skjold »kom drivende paa et Skib med store Kostbarheder til Danmark, hvor Folket dengang var høvdingeløst, og opfostrede sig en Konge i ham ...« Ikke et Ord om indre Splid i Landet. Noten svarer nøje til Texten i Krønike-Riim-Fragmentet.

Som Slutfacit kan da anføres, at Grundtvigs første større poetiske Skildring af Skjolds Komme til Danmark efter al Sandsynlighed var det fremdragne Udkast til Krønike-Riimet om Danskerne, og at dette Udkast maa dateres til 1828 . Dodanim-Redaktionen, der efter al Sandsynlighed bygger paa dette Udkast, kan da ikke være ældre end fra nævnte Aar.

Det er iøvrigt meget tænkeligt, at netop Grundtvigs Syssel med Krønike-Riimene (der jo var en Verdenshistorie »til Børne-Lærdom «), har tilskyndet ham til at udforme et nationalhistorisk Sidestykke: Omdigtningen af Den gamle danske Rimkrønike, saaledes at Dodanim-Redaktionen er fra Efteraaret eller Vinteren I828 og de af Svend Grundtvig (i PS V, p. 390-398) trykte Rim, som Toldberg benævner »den ægte I826-redaktion« (anf. Afhandl., p. 79) fra en lidt senere Tid. 